\title{
Depth distribution of the amoebic gill disease agent, Neoparamoeba perurans, in salmon sea-cages
}

\author{
Daniel W. Wright ${ }^{1, *}$, Barbara Nowak ${ }^{2}$, Frode Oppedal ${ }^{3}$, Andrew Bridle ${ }^{2}$, \\ Tim Dempster ${ }^{1}$ \\ ${ }^{1}$ Sustainable Aquaculture Laboratory - Temperate and Tropical (SALTT), School of Biosciences, University of Melbourne, \\ Parkville, VIC 3010, Australia \\ ${ }^{2}$ Institute of Marine and Antarctic Studies, University of Tasmania, Launceston, TAS 7250, Australia \\ ${ }^{3}$ Institute of Marine Research, 5984 Matredal, Norway
}

\begin{abstract}
Identifying where and when parasites occur in farming environments is vital to understand transmission dynamics and develop preventative measures that reduce host-parasite encounters. A major parasite concern for Atlantic salmon farming is Neoparamoeba perurans, a marine amoeba that causes the potentially fatal amoebic gill disease (AGD), for which few control options exist. We explored whether free-living $N$. perurans abundance differs among depths in commercial Atlantic salmon Salmo salar sea-cages. Water samples collected from the surface to $10 \mathrm{~m}$ depth at multiple cage sites and times, and subsequently subjected to qPCR analysis, revealed that $N$. perurans abundance was influenced by depth at the time of year when amoeba numbers were highest, with more amoebae in surface waters. No distinct depth patterns were observed when amoebae were in low abundance. Across all times, temperature and salinity were largely homogeneous throughout cage depths. Possible factors explaining the presence of amoebae at the surface are discussed. Our results suggest that excluding caged salmon from upper cage depths where $N$. perurans is more abundant could be an effective management strategy to reduce the speed at which initial infections occur and delay the development of AGD outbreaks.
\end{abstract}

KEY WORDS: Parasite control $\cdot$ Atlantic salmon $\cdot$ Salmo salar $\cdot$ Neoparamoeba perurans $\cdot$ Depth distribution $\cdot$ Sea-cages

\section{INTRODUCTION}

Amoebic gill disease (AGD), caused by the parasitic marine amoeba Neoparamoeba perurans (Amoebozoa, Dactylopodida), is an escalating concern for salmon farms globally (Nowak 2012, Rodger 2013). The condition manifests as potentially lethal gill lesions, and AGD outbreaks can result in stock losses exceeding 50\% (Munday et al. 1990, Nowak 2012). Currently, the only treatments available are frequent baths in fresh water or hydrogen peroxide $\left(\mathrm{H}_{2} \mathrm{O}_{2}\right)$ (Adams et al. 2012, Nowak 2012), while attempts to develop vaccines or chemical treatments and to selectively breed salmon for AGD resistance con-

\footnotetext{
${ }^{*}$ Corresponding author: danielw1@student.unimelb.edu.au
}

tinue to be pursued (Kube et al. 2012, Nowak 2012). However, opportunities to minimise host-parasite contact have not been thoroughly investigated. Recently, reduction in sea lice Lepeophtheirus salmonis infection levels has been achieved by moving salmon deeper to avoid surface waters where free-living infective stages congregate (Frenzl et al. 2014, F. Oppedal et al. unpubl.). Depending on the depth distribution of $N$. perurans, similar measures may help control AGD.

Little information is available on $N$. perurans biology and ecology (Nowak 2012) because the species was only recently taxonomically resolved (Young et al. 2007, 2008) and definitively proven to cause AGD (Crosbie et al. 2012). The parasite uses resources

() The authors 2015. Open Access under Creative Commons by Attribution Licence. Use, distribution and reproduction are unrestricted. Authors and original publication must be credited. 
from fish gills and the external environment (Crosbie et al. 2012), and has been detected from water in seacages holding salmon diagnosed with AGD (Bridle et al. 2010). The only amoeba depth distribution study in AGD-affected salmon cages indicated that the highest densities of Paramoeba spp. and Neoparamoeba spp. occurred at middle and deep cage depths (5 and $10 \mathrm{~m}$, opposed to $0.5 \mathrm{~m}$; Douglas-Helders et al. 2003), where greatest salmon swimming densities are predicted during daylight (Oppedal et al. 2011). This suggests that areas of high fish density yield increased amoeba numbers in the water column, which is supported by fish density increasing the rate of AGD progression in tanks (Crosbie et al. 2010). However, no study of amoeba depth distribution in commercial sea-cages has specifically detected $N$. perurans, included surface samples or sampled throughout a range of AGD-affected farm areas.

The life history of related amoebae has received more attention. Dactylopodida family members (naked lobose amoebae, Adl et al. 2005) do not form cysts and reproduce via asexual mitosis (Page 1970, Kent et al. 1988). Both $N$. perurans and the related $N$. pemaquidensis assume transitional floating forms (with elongated pseudopodia) and growing locomotive trophozoite forms (flattened and irregularshaped) (Kent et al. 1988, Lee et al. 2006, Crosbie et al. 2012). Floating forms of $N$. pemaquidensis stripped of suitable attachment substrate survive without feeding or multiplying for up to $3 \mathrm{wk}$, then readily grow and reproduce once substrate is reinstated (Martin 1985). Martin (1985) suggested that this state was adapted to passive movement in surface currents, which is corroborated by the evidence that naked amoebae pseudopodia withstand compression (Ueda \& Ogihara 1994), and the detection of $N$. pemaquidensis in surface microlayers $<150 \mu \mathrm{m}$ deep (Davis et al. 1978). Surface microlayers are unique, ecologically distinct environments known to support complex protist communities (Cunliffe et al. 2011). Elucidating whether $N$. perurans resides in these habitats may help unravel the dispersal, geographic distribution, host-to-host transmission and population maintenance of this parasite. If prevalent at the surface of sea-cage environments, $N$. perurans could be avoided by manipulating caged salmon swimming behaviour.

Environmental variables that increase AGD risk and affect $N$. perurans are also expected drivers of $N$. perurans abundance and distribution in sea-cages. High salinity (>32 ppt) and periods of low rainfall strongly correlate with AGD outbreaks (Munday et al. 2001, Mitchell \& Rodger 2011, Nowak 2012). Fur- ther, efficacy of freshwater baths in assuaging AGD infections in salmon (Nowak 2012), along with the crenation, ceased growth and death of $N$. pemaquidensis cells at low salinities (Lee et al. 2006), infer that $N$. perurans are susceptible to salinity changes. Similarly, higher AGD occurrence is linked to elevated temperatures $\left(12-20^{\circ} \mathrm{C}\right.$; Munday et al. 2001, Mitchell \& Rodger 2011), and N. pemaquidensis showed progressively reduced growth at lower temperatures between 5 and $20^{\circ} \mathrm{C}$ (Kent et al. 1988). Salmon cages in estuary and fjord sites can be subject to strong vertical gradients and temporal variability in temperature and salinity (Douglas-Helders et al. 2005, Johansson et al. 2006, Oppedal et al. 2007). Thus, variation in N. perurans abundance and distribution through space and time may be temperature and salinity driven.

Here, we tested the influence of depth on the abundance of $N$. perurans in Atlantic salmon Salmo salar sea-cages within southeast Tasmanian farms from early autumn when AGD outbreaks are typical, to early winter when they diminish (Clark \& Nowak 1999). Water sampling included both sea-surface and deeper cage depths. We hypothesised that the highest $N$. perurans densities may occur in surface waters where related marine amoebae have been detected or lower in the water column where amoeba-shedding salmon typically school in sea-cages during the day. Vertical environmental profiles were conducted to help explain $N$. perurans abundance. With freshwater bathing treatments likely decreasing free-living amoeba abundance (Parsons et al. 2001, Crosbie et al. 2010), the effects of time since freshwater bathing in cages were also explored.

\section{MATERIALS AND METHODS}

\section{Water sampling}

We collected water samples from 9 commercial salmon cages at 3 farm sites ( 3 cages site ${ }^{-1}$ ) in upper and lower sections of the D'Entrecasteaux Channel in southeast Tasmania (Fig. 1; operated by TASSAL and Huon Aquaculture). Cages were spatially separated $(0.3-30 \mathrm{~km})$ to incorporate a range of salmon cage conditions in the region, and all cages were circular and of equal diameter (diameter $=38 \mathrm{~m}$, circumference $=120 \mathrm{~m}$, cage depth $=10-19 \mathrm{~m}$ ). Water sampling occurred at the downstream end of cages and $9.5 \mathrm{~m}$ within them $(1 / 4$ cage diameter) where schooling fish were expected to reside. For each sample, water was obtained with a weighted 1.7 l Niskin 


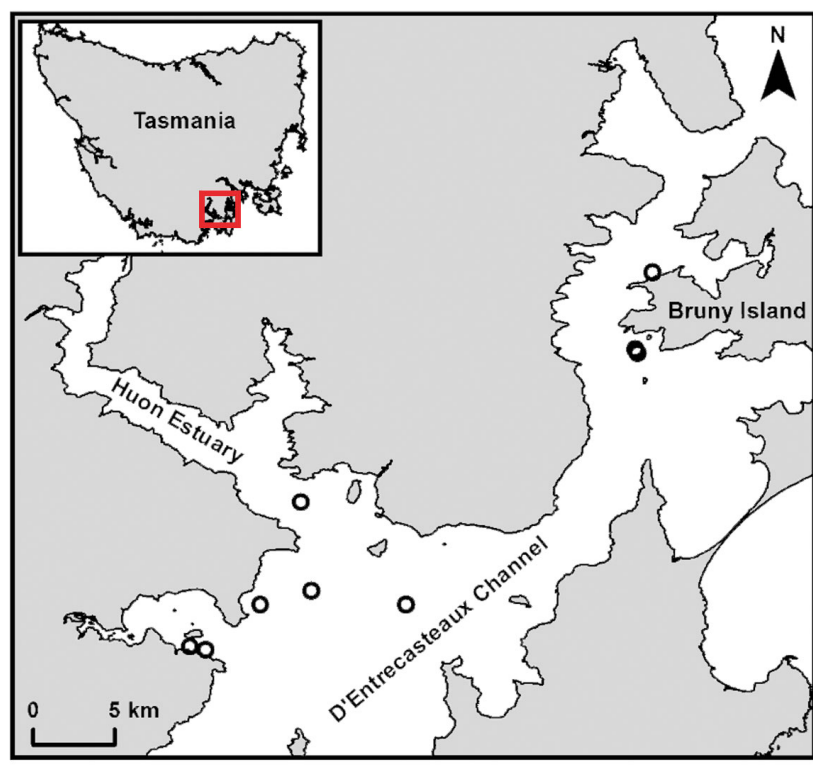

Fig. 1. Location of the 9 salmon cages sampled (open circles) in upper and lower sections of the D'Entrecasteaux Channel, situated in southeast Tasmania (inset). Note that 2 circles overlap for cages close together off Bruny Island

bottle (General Oceanics) via a rope system that allowed an operator to horizontally and vertically move the device and close it at a sampling depth (using a trigger weight) from the cage edge. This procedure minimised disruption of normal fish behaviour by the operator, although movements of the Niskin bottle between sampling depths and the cage edge during sampling events may have affected local salmon behaviour and amoeba abundances. Water was then transferred to two 11 sterilised plastic bottles and stored on ice during transport until being refrigerated. After each sample was collected, the sampler was flushed with fresh water and dried with fresh paper towel. We sampled at depths of the seasurface layer by slightly raising the top of the sampler above water $(0 \mathrm{~m})$ and $1,2.5,5$ and $10 \mathrm{~m}$ in each cage at 3 separate times in early autumn (time 1, 16-21 March), late autumn (time 2, 28-30 April) and early winter (time 3, 16-20 June) 2014. According to farm records, AGD was most severe in the study cages at time 1 compared to the other periods (Table 1). A single sample was taken at each of the 5 depths for the 9 cages at each of the 3 times (totalling 135 samples).

\section{Amoeba quantification}

Within $24 \mathrm{~h}$ of collection, water samples were filtered. The filtration system consisted of filters $(1.2 \mu \mathrm{m}$ pore size, $47 \mathrm{~mm}$ diameter, GF/C Whatman glass microfibre, Sigma-Aldrich) inserted into a Nalgene ${ }^{\mathrm{TM}}$ filter holder with receiver (Thermoscientific) connected to a Rocker 300 vacuum pump (JAVAC) operated at $30 \mathrm{kPa}$. A sample contained in two 11 bottles was passed through the same filter. To prevent contamination, the filter holder unit and filter-handling forceps were washed in a 1:10 dilution of household bleach $(4.2 \%$ sodium hypochlorite) in fresh water, rinsed 10 times in fresh water and dried thoroughly. Filters were then stored in $5 \mathrm{ml}$ vials containing $1 \mathrm{ml}$ of lysis buffer ( $4 \mathrm{M}$ urea, $1 \% \mathrm{SDS}, 0.2 \mathrm{M} \mathrm{NaCl}, 1 \mathrm{mM}$ sodium citrate), and kept at room temperature for 10 min until being frozen at $-20^{\circ} \mathrm{C}$. As a decontamination precaution, a new sterile $3 \mathrm{ml}$ syringe for dispensing lysis buffer was used for each sample.

After filtration and digestion with Proteinase $\mathrm{K}$ in lysis buffer, thawed samples were divided into 2 equal aliquots, providing a back-up sample for checking or confirming results. Vortexing was used to lyse amoeba trophozoites trapped by the filter paper. Total nucleic acid (TNA) was then extracted from samples supplemented with $5 \mu$ l Proteinase K (20 mg ml${ }^{-1}$; Bioline) and incubated at $55^{\circ} \mathrm{C}$ for 30 min with occasional vortexing. Undigested protein was removed by precipitation with the addition of $250 \mu \mathrm{l}$ of $7.5 \mathrm{M}$ ammonium acetate and centrifugation at $14000 \times g$ for $5 \mathrm{~min}$. Nucleic acids were then precipitated from the supernatant with the addition of 1 volume isopropanol and centrifugation at $16000 \times g$ for $30 \mathrm{~min}$. The nucleic acid pellet was rinsed twice with $70 \%$ ethanol and resuspended in $50 \mu \mathrm{l}$ of TE buffer (10 mM Tris, 1 mM EDTA, pH 8). Real-time PCR assays for Neoparamoeba perurans were conducted to quantify amoeba abundance for each sample using a CFX Connect PCR Detection System (Bio-Rad) to detect an N. perurans-specific $18 \mathrm{~S}$ rRNA sequence as described by Bridle et al. (2010), but with modifications (Bridle et al. 2015).

Table 1. Summary statistics of amoebic gill disease (AGD)related variables across study cages at each time. Values presented are means $\pm \mathrm{SE}$ (with ranges in parentheses)

\begin{tabular}{|c|c|c|c|c|}
\hline Time & $\begin{array}{l}\text { No. } \\
\text { cages }\end{array}$ & $\begin{array}{l}\text { Pre-bath AGD } \\
\text { prevalence (\%) }\end{array}$ & $\begin{array}{l}\text { Time since } \\
\text { bathing }(d)\end{array}$ & $\begin{array}{c}\text { Fish stocking } \\
\text { density }\left(\mathrm{kg} \mathrm{m}^{-3}\right)\end{array}$ \\
\hline 1 & 9 & $\begin{array}{c}64.0 \pm 12.0 \\
(6-100)\end{array}$ & $\begin{array}{l}15.3 \pm 2.8 \\
(1-30)\end{array}$ & $\begin{array}{l}4.4 \pm 0.5 \\
(2.7-6.8)\end{array}$ \\
\hline 2 & 9 & $\begin{array}{c}43.4 \pm 13.6 \\
(0-100)\end{array}$ & $\begin{array}{l}17.1 \pm 4.6 \\
(1-46)\end{array}$ & $\begin{array}{l}4.5 \pm 0.8 \\
(0.3-8.7)\end{array}$ \\
\hline 3 & 9 & $\begin{array}{c}54.2 \pm 10.7 \\
(10-100)\end{array}$ & $\begin{array}{c}47.7 \pm 6.7 \\
(14-71)\end{array}$ & $\begin{array}{l}5.6 \pm 0.9 \\
(1.3-8.4)\end{array}$ \\
\hline
\end{tabular}


Firstly, we incorporated a 6-carboxyhexafluorescein (HEX)-labelled and Black Hole Quencher 1 (BHQ1)quenched Taqman probe at $100 \mathrm{nM}$ per $20 \mu \mathrm{l}$ reaction volume: 5'-TTG TTG TGA TAT GTA CTT CTC CTT ACT-3' that anneals between the QNperF3 and QNperR3 binding sites on the 18S rRNA gene (Bridle et al. 2010). Secondly, real-time PCR cycling conditions consisted of 45 cycles of $95^{\circ} \mathrm{C}$ for $10 \mathrm{~s}$ and $55^{\circ} \mathrm{C}$ for $30 \mathrm{~s}$, for combined annealing and extension.

A standard curve that allowed accurate copy numbers to be determined for each sample was generated for each real-time PCR run using a 417 bp gBlock (Integrated DNA Technologies). The gBlock consisted of synthetic double-stranded DNA containing the $146 \mathrm{bp} 18 \mathrm{~S} N$. perurans rDNA sequence targeted by the QNperF3 and QNperR3 real-time PCR oligonucleotides. The standard curve consistently had an efficiency of 98-101\% and linearity (coefficient of determination) of 0.99-1 over an 8-log linear dynamic range. The number of copies in each sample was determined from an initial input of $2 \mu \mathrm{l}$ of undiluted and 1:10 diluted TNA extract in each $20 \mu \mathrm{l}$ reaction volume. Importantly, no evidence of inhibition was found in any of the samples based on a comparison of the copy numbers calculated in the undiluted and 1:10 diluted TNA. Conversion from copy numbers to the number of $N$. perurans was calculated from the estimated 2880 copies of $18 \mathrm{~S}$ rDNA per $N$. perurans trophozoite, as previously reported (Bridle et al. 2010). Furthermore, a known number of $N$. perurans trophozoites that were individually counted under a microscope were similarly filtered and used as a positive control for amplification, DNA extraction efficiency and copy number to trophozoite conversion.

Samples taken from 1 and $5 \mathrm{~m}$ in 1 cage at time 1 were not analysed due to technical problems. $N$. perurans abundance was recalculated to cells $\mathrm{l}^{-1}$ for each sample to account for differences in sample volumes.

\section{Environmental and AGD-related variables}

In conjunction with water samples within each cage, we recorded depth profiles of salinity, temperature and oxygen using a Hydrolab DS5X water quality multiprobe (Hach Environmental) between 0 and $10.25 \mathrm{~m}$. For each depth profile, data were condensed to mean values at $0.5 \mathrm{~m}$ intervals. For each study cage, information on days since last freshwater bathing, stocking density and AGD prevalence (percentage of fish with macroscopic
AGD lesions or spots out of a total of 30 to 40 fish) was collected from farm records. AGD prevalence (termed pre-bath AGD prevalence hereafter) was assessed immediately prior to the previous freshwater bath in a given cage and did not represent that at the exact time of sampling events.

\section{Statistical analyses}

To assess which predictor variables were most strongly associated with amoeba abundance at each time, we used generalised linear mixed model (GLMM) analyses (McCullagh \& Nelder 1989) in R ( $\mathrm{R}$ Core Development Team, version 3.1.0) using glmmADMB and MuMIn packages. The response variable was amoeba abundance (cells $\mathrm{l}^{-1}$ ), with these data fourth-root transformed. An a priori selection of predictor variables of depth, time since freshwater bathing, water temperature and salinity were classed as fixed effects (see expected effects in Table 2). Site was included as a random factor in each model. The best model was selected using Akaike's information criterion with a correction for small sample size $\left(\mathrm{AIC}_{\mathrm{c}}\right)$ (Bedrick \& Tsai 1994). A model with the lowest $\mathrm{AIC}_{\mathrm{C}}$ value was deemed the most parsimonious. In the case that a model was compared to another with an additional variable, if $\Delta \mathrm{AIC}_{\mathrm{C}}$ differed by $\leq 2$, the simpler model was considered the better fit. Akaike weights $\left(w_{i}\right)$ were calculated to indicate the relative likelihood of a model based on all models in the candidate set, with models of higher weight having increased support (Burnham \& Andersen 2002). Data were checked for normality with Kolmogorov-Smirnov tests and equality of variance using residual plots and transformed as appropriate prior to analysis. Errors represent standard errors unless otherwise stated and significance levels were set at $\alpha=0.05$.

Table 2. Predictor variables selected for use in generalised linear mixed models and their expected effects on Neoparamoeba perurans amoeba abundance. AGD: amoebic gill disease

\begin{tabular}{|lccc|}
\hline Predictor & Conditions & Correlation & Cause \\
\hline Depth & High loads & $\begin{array}{c}\text { More at surface } \\
\text { or fish depth }\end{array}$ & Fish or amoebae \\
Low loads & $\begin{array}{c}\text { No effect } \\
\text { Positive }\end{array}$ & Low AGD levels \\
$\begin{array}{l}\text { Time since } \\
\text { bathing }\end{array}$ & & AGD prevalence \\
$\begin{array}{l}\text { Temperature } \\
\text { Salinity }\end{array}$ & & Positive & AGD prevalence \\
\end{tabular}




\section{RESULTS}

\section{Cage environment}

At each sampling time, the water column was largely unstratified, with little vertical difference in temperature, salinity and dissolved oxygen saturation among cages (Fig. 2). While temperature varied markedly among times, becoming progressively cooler, salinity $($ mean $=35.1 \pm 0.02$; range $=28.5-$ $35.6 \mathrm{ppt}$ ) and dissolved oxygen (mean $=87.6 \pm 0.2$; range $=72.9-96.8 \%$ saturation) remained largely unchanged (Fig. 2).

\section{Amoeba abundance and AGD-related variables}

Mean amoeba abundance was highest at time 1 $\left(\right.$ mean $=4.7 \pm 2.0 ;$ range $=0-62.3$ cells $\left.^{-1}\right)$ compared

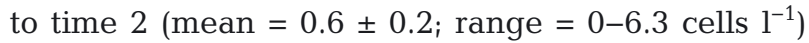
and time $3\left(\right.$ mean $=0.4 \pm 0.1 ;$ range $=0-3.9$ cells l$^{-1}$;
Fig. 3). Time 1 coincided with the highest pre-bath AGD prevalence recorded across cages than at other times (Table 1). Additionally, times 1 and 2 had shorter times until freshwater bathing (i.e. more frequent bathing treatments to combat AGD) for all cages sampled than at time 3. Overall stocking densities for study cages remained relatively constant among times (Table 1).

\section{Predictor variable effects on amoeba abundance}

At time 1, when amoeba numbers were greatest, abundance differences were best explained by the GLMM using depth, with higher abundance at shallower depths $(\beta=0.05 \pm 0.02, z=2.13, p=0.0334$; Fig. 3, and see Table S1 in the Supplement at www.int-res.com/articles/suppl/q007p067_supp.pdf). At time 2 when fewer amoebae were detected across all samples, the model best explaining abundance used time since bathing and pre-bath AGD prevalence (Table S2). Inspection of the model coefficients revealed that amoeba abundance was positively influenced by time since bathing $(\beta=0.03 \pm 0.01, z=5.02, p<$ 0.0001; Table S2). At time 3, when overall amoeba abundances were lowest across all 3 times, the model with time since bathing best explained amoeba abundance (Table S3). Again, abundance was positively affected by time since bathing $(\beta=0.01 \pm 0.00, z=2.1, p=$ 0.0320; Table S3).

\section{DISCUSSION}

This is the first detailed study on the distribution of free-living Neoparamoeba perurans, the agent responsible for AGD in farmed salmon, within full-scale operational farms. Our results found depth to be the most important determinant of amoeba abundance when the highest amoeba levels and AGD prevalence were observed in early autumn (time 1), with more amoebae in surface waters of salmon cages. In late autumn (time 2) and early winter (time 3 ), when amoeba numbers and AGD prevalence were low, longer intervals since freshwater bathing consistently explained higher amoeba abundance, rather than depth. Depth pat-
Fig. 2. Temperature, salinity and dissolved oxygen (DO) saturation vertical profiles between 0 and $10 \mathrm{~m}$ (mean $\pm \mathrm{SE}$, values calculated from 9 cages at $0.5 \mathrm{~m}$ intervals) for time 1 (top row), time 2 (middle row) and time 3 (bottom row) 

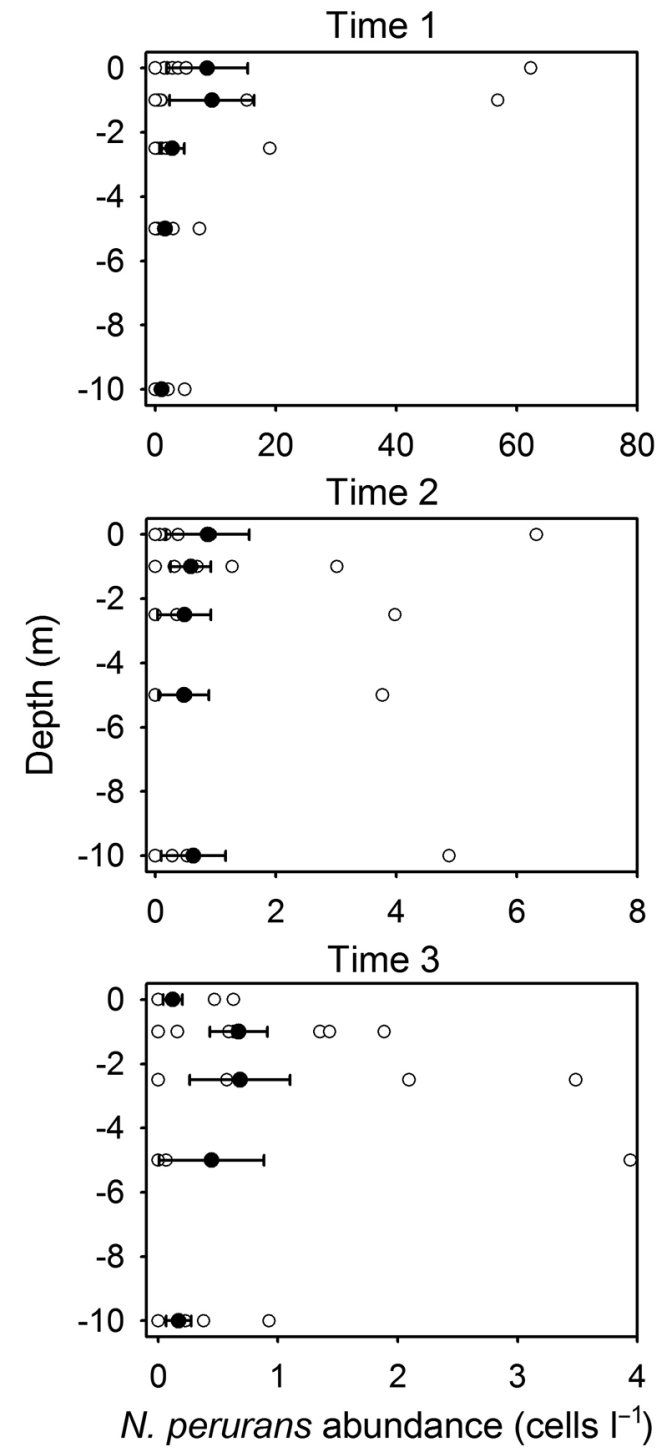

Fig. 3. Individual data points (open circles) overlaid with means $\pm \mathrm{SE}$ (solid circles) of abundance of free-living Neoparamoeba perurans plotted against depth for each time. Note the different $x$-axis scales among times for abundance cells

terns in amoeba numbers were not driven by environmental variables, which were predominantly homogeneous throughout the water column at all sampling times. The cause of the vertical distribution patterns of $N$. perurans is unresolved because the depth of salmon, which shed amoebae into surrounding waters, was not measured. If high densities of amoebae in surface waters are common and unrelated to fish distribution, these findings could have significant implications for AGD epidemiology and control development. Such a pattern suggests that moving salmon away from the surface in cages through behavioural or environmental manipulations would minimise contact with amoebae and slow AGD progression at the individual level and postpone AGD outbreaks at the population level.

\section{Amoeba-driven pattern}

One possible explanation for surface concentrations of $N$. perurans is its life history. Closely related $N$. pemaquidensis have been found in high numbers in the surface micro-layer (150 $\mu \mathrm{m}$ deep, Davis et al. 1978), in either an attached form on bacterialenriched organic matter or a free-floating form (Martin 1985). In floating forms, $N$. pemaquidensis survives up to $3 \mathrm{wk}$, allowing amoebae positioned in surface layers to passively disperse in currents and opportunistically colonise bacterial-enriched organic matter (Martin 1985) or the gills of fish hosts. Floating $N$. perurans forms and other motionless marine protists may orient themselves vertically into surface layers by altering cell mass via gas vacuoles (Ogden 1991), or through active water transport, organic solute synthesis and ion exclusion mechanisms in intracellular vacuoles (Raven \& Doblin 2014). Depthspecific neuston (associated with the air-water interface) or plankton (below the surface) organisms in predator-prey or competitor relationships with $N$. perurans may also drive its distribution.

\section{Fish-driven pattern}

Alternatively, $N$. perurans abundance could be influenced by AGD-affected salmon behaviour in cages. This was suggested in a previous study of day-time depth distribution of paramoebae in salmon seacages, which found highest abundances at middle and deep cage depths (Douglas-Helders et al. 2003), where salmon are expected to school in daylight hours given homogenous conditions with depth and low hunger state of the fish (Oppedal et al. 2011). In contrast, our data suggest that amoeba numbers were highest in surface waters when salmon were expected to school deep in cages according to prevailing light, temperature, salinity and dissolved oxygen conditions (Oppedal et al. 2011). It is noteworthy that Douglas-Helders et al. (2003) did not specifically detect $N$. perurans (the antibody used was not species-specific) or sample the surface micro-layer, and that sampling during an AGD outbreak only occurred at 1 estuarine site when salinity was $28 \mathrm{ppt}$ at $0.5 \mathrm{~m}$ depth. While our study supports the notion that salmon swimming depth is not linked to N. perurans 
distribution, this is yet to be determined, and is particularly difficult to predict in Tasmania where detailed studies of the salmon swimming depth preferences in commercial sea-cages are yet to be conducted.

Salmon swimming behaviour in sea-cages could conceivably lead to a surface-rich distribution of $N$. perurans in several ways. Fish can occupy upper cage depths when feeding or hungry, and at night (Oppedal et al. 2011). Concomitantly, physostomous Atlantic salmon surface regularly to swallow air to inflate their open swim bladder for buoyancy control (Dempster et al. 2011). In such events, salmon can reach high swim speeds, manoeuvre sharply and completely jump out of the water, potentially facilitating amoeba dislodgement from gills in surface waters. AGD-suffering fish are also reported to swim lethargically near the surface in sea-cages and may lead to $N$. perurans-rich surface waters (Munday et al. 2001). Finally, upwelling can occur downstream of salmon schools in sea-cages, especially when they display fast daytime swim speeds (see review by Klebert et al. 2013), which may lift $N$. perurans shed from fish gills into surface layers.

\section{CONCLUSIONS}

The discovery of Neoparamoeba perurans in surface layers during AGD outbreaks is significant in light of the current view of AGD epidemiology. While it is well established that amoebae transfer between neighbouring fish in tank systems (Munday et al. 2001), our study indicates that fish respiring in upper cage depths may be susceptible to $N$. perurans colonisation during AGD outbreaks. Cultured salmon typically enter these depths prior to or during feeding, at elevated hunger levels, when jumping to refill their swim bladders, and at night, and would thus be vulnerable to infections. Inhabiting surface waters would also aid dispersal of $N$. perurans among farms and over broad geographical areas, and surface currents may play an important role in the rapid and expanding spread of AGD between salmon farming regions (e.g. Rodger 2013).

If surface-oriented $N$. perurans is a robust pattern in AGD-affected salmon cages that is not driven by fish swimming depth, moving caged salmon away from shallow waters could be an important strategy for controlling AGD in salmon farming. Whether shallow infected fish cause surface-dwelling amoebae requires investigation, because moving such individuals deep could then have no effect on or worsen
AGD spread in cages. Recently, luring caged salmon deeper using submerged artificial lights and forcing salmon to swim deep by restricting the surface access space of cages has successfully reduced infections by surface-dwelling infective sea lice stages (Frenzl et al. 2014, F. Oppedal et al. unpubl.). Similar preventative behavioural and environmental approaches may offer new control options for AGD to augment current freshwater and chemical bathing treatments. However, further study is needed to ascertain the dynamics of $N$. perurans depth distribution, for instance at inter-annual and inter-regional scales, throughout diel cycles, at farm versus reference sites, in relation to stratification and for different hydrodynamic conditions.

Acknowledgements. We thank Francisca Samsing and Fletcher Warren-Myers for assistance in the field, and Carlos Zarza and Linda Sams from Tassal and Steve Percival from Huon Aquaculture for assistance. Luke Barrett advised on statistical analyses. Funding was provided by an Australian Research Council Future Fellowship grant to T.D.

\section{LITERATURE CITED}

Adams MB, Crosbie PBB, Nowak BF (2012) Preliminary success using hydrogen peroxide to treat Atlantic salmon, Salmo salar L., affected with experimentally induced amoebic gill disease (AGD). J Fish Dis 35:839-848

Adl SM, Simpson AGB, Farmer MA, Andersen RA and others (2005) The new higher level classification of eukaryotes with emphasis on the taxonomy of protists. J Eukaryot Microbiol 52:399-451

Bedrick EJ, Tsai CL (1994) Model selection for multivariate regression in small samples. Biometrics 50:226-231

Bridle AR, Crosbie PBB, Cadoret K, Nowak BF (2010) Rapid detection and quantification of Neoparamoeba perurans in the marine environment. Aquaculture 309:56-61

Bridle AR, Davenport DL, Crosbie PBB, Polinski M, Nowak BF (2015) Neoparamoeba perurans loses virulence during clonal culture. Int J Parasitol 45:575-578

Burnham KP, Andersen DR (2002) Model selection and multimodel inference: a practical information-theoretic approach, 2nd edn. Springer, New York, NY

> Clark A, Nowak BF (1999) Field investigations of amoebic gill disease in Atlantic salmon, Salmo salar L., in Tasmania. J Fish Dis 22:433-443

Crosbie PBB, Bridle AR, Leef MJ, Nowak BF (2010) Effects of different batches of Neoparamoeba perurans and fish stocking densities on the severity of amoebic gill disease in experimental infection of Atlantic salmon, Salmo salar L. Aquacult Res 41:505-516

Crosbie PBB, Bridle AR, Cadoret K, Nowak BF (2012) In vitro cultured Neoparamoeba perurans causes amoebic gill disease in Atlantic salmon and fulfils Koch's postulates. Int J Parasitol 42:511-515

Cunliffe M, Upstill-Goddard RC, Murrell JC (2011) Microbiology of aquatic surface microlayers. FEMS Microbiol Rev 35:233-246

Davis PG, Caron DA, Seiburth JM (1978) Oceanic amoebae 
from the North Atlantic: culture, distribution, and taxonomy. Trans Am Microsc Soc 97:73-88

- Dempster T, Kristiansen TS, Korsøen ØJ, Fosseidengen JE, Oppedal F (2011) Technical note: modifying Atlantic salmon (Salmo salar) jumping behavior to facilitate innovation of parasitic sea lice control techniques. J Anim Sci 89:4281-4285

$>$ Douglas-Helders GM, O'Brien DP, McCorkell BE, Zilberg D, Gross A, Carson J, Nowak BF (2003) Temporal and spatial distribution of paramoebae in the water columna pilot study. J Fish Dis 26:231-240

Douglas-Helders M, Nowak B, Butler R (2005) The effect of environmental factors on the distribution of Neoparamoeba pemaquidensis in Tasmania. J Fish Dis 28: 583-592

Frenzl B, Stien LH, Cockerill D, Oppedal F and others (2014) Manipulation of farmed Atlantic salmon swimming behaviour through the adjustment of lighting and feeding regimes as a tool for salmon lice control. Aquaculture 424-425:183-188

Johansson D, Ruohonen K, Kiessling A, Oppedal F, Stiansen JE, Kelly M, Juell JE (2006) Effect of environmental factors on swimming depth preferences of Atlantic salmon (Salmo salar L.) and temporal and spatial variations in oxygen levels in sea cages at a fjord site. Aquaculture 254:594-605

Kent ML, Sawyer TK, Hedrick RP (1988) Paramoeba pemaquidensis (Sarcomastigophora: Paramoebidae) infestation of the gills of coho salmon Oncorhynchus kisutch reared in sea water. Dis Aquat Org 5:163-169

Klebert P, Lader P, Gansel L, Oppedal F (2013) Hydrodynamic interactions on net panel and aquaculture fish cages: a review. Ocean Eng 58:260-274

Kube PD, Taylor RS, Elliott NG (2012) Genetic variation in parasite resistance of Atlantic salmon to amoebic gill disease over multiple infections. Aquaculture 364-365: 165-172

Lee LEJ, Van Es SJ, Walsh SK, Rainnie DJ, Donay N, Summerfield R, Cawthorn RJ (2006) High yield and rapid growth of Neoparamoeba pemaquidensis in co-culture with a rainbow trout gill-derived cell line RTgill-W1. J Fish Dis 29:467-480

Martin RE (1985) Population growth in stationary and suspension culture of Paramoeba pemaquidensis Page (Amoebida, Paramoebidae). J Protozool 32:738-739

McCullagh P, Nelder J (1989) Generalised linear models, 2nd edn. Chapman and Hall, London

Editorial responsibility: Marianne Holmer, Odense, Denmark
Mitchell SO, Rodger HD (2011) A review of infectious gill disease in marine salmonid fish. J Fish Dis 34: 411-432

Munday BL, Foster CK, Roubal FR, Lester RJG (1990) Paramoebic gill infection and associated pathology of Atlantic salmon, Salmo salar and rainbow trout, Salmo gairdneri in Tasmania. In: Perkins FO, Cheng TC (eds) Pathology in marine science. Academic Press, San Diego, CA, p 215-222

Munday BL, Zilberg D, Findlay V (2001) Gill disease of marine fish caused by infection with Neoparamoeba pemaquidensis. J Fish Dis 24:497-507

Nowak BF (2012) Neoparamoeba perurans. In: Woo PTK, Buchmann K (eds) Fish parasites: pathobiology and protection. CAB International, Wallingford, p 1-18

Ogden CG (1991) The biology and ultrastructure of an agglutinate testate amoeba Difflugia geosphaira sp. nov. (Protozoa, Rhizopoda). Arch Protistenkd 140:141-150

Oppedal F, Juell JE, Johansson D (2007) Thermo- and photoregulatory swimming behaviour of caged Atlantic salmon: implications for photoperiod management and fish welfare. Aquaculture 265:70-81

> Oppedal F, Dempster T, Stien LH (2011) Environmental drivers of Atlantic salmon behaviour in sea-cages: a review. Aquaculture 311:1-18

Page FC (1970) Two new species of Paramoeba from Maine. J Protozool 17:421-427

> Parsons H, Nowak B, Fisk D, Powell M (2001) Effectiveness of commercial freshwater bathing as a treatment against amoebic gill disease in Atlantic salmon. Aquaculture 195: 205-210

Raven JA, Doblin MA (2014) Active water transport in unicellular algae: where, why, and how. J Exp Bot 65: 6279-6292

Rodger H (2013) Amoebic gill disease (AGD) in farmed salmon (Salmo salar) in Europe. Fish Vet J 14:16-26

> Ueda M, Ogihara S (1994) Microtubules are required in amoeba chemotaxis for preferential stabilization of appropriate pseudopods. J Cell Sci 107:2071-2079

> Young ND, Crosbie PBB, Adams MB, Nowak BF, Morrison RN (2007) Neoparamoeba perurans n. sp., an agent of amoebic gill disease of Atlantic salmon (Salmo salar). Int J Parasitol 37:1469-1481

Young ND, Dyková I, Snekvik K, Nowak BF, Morrison RN (2008) Neoparamoeba perurans is a cosmopolitan aetiological agent of amoebic gill disease. Dis Aquat Org 78: $217-223$

Submitted: November 3, 2014; Accepted: June 17, 2015 Proofs received from author(s): July 13, 2015 